\title{
NEW EVIDENCE OF LINDENIA TETRAPHYLLA (VANDER LINDEN, 1825) (ODONATA, GOMPHIDAE) REPRODUCTION AT THE NORTH-WESTERN BORDER OF ITS DISTRIBUTION
}

\author{
Marina Vilenica ${ }^{1, *}$, Antun Alegro ${ }^{2}$, Nikola Koletić ${ }^{2}$ \\ \& Zlatko Mihaljević ${ }^{2}$
}

${ }^{1}$ University of Zagreb, Faculty of Teacher Education, Department in Petrinja, Petrinja, Croatia ${ }^{2}$ University of Zagreb, Faculty of Science, Department of Biology, Zagreb, Croatia

Vilenica, M., Alegro, A., Koletić, N. \& Mihaljević, Z.: New evidence of Lindenia tetraphylla (Vander Linden, 1825) (Odonata, Gomphidae) reproduction at the north-western border of its distribution. Nat. Croat., Vol. 25, No. 2., 287-294, 2016, Zagreb.

A total of 12 dragonfly species were recorded at Vlačine Reservoir in the Dinaric Western Balkan region (ER 5) in Croatia. Habitat conditions, i.e. vegetation structure and physico-chemical water properties of the reservoir, are presented and discussed. Habitat conditions were suitable for life cycle completion of Mediterranean species such as Lindenia tetraphylla and Selysiothemis nigra. Exuviae of $L$. tetraphylla represent new evidence of the species' reproduction in the north-western border of its distribution

Key words: exuviae, breeding site, emergence, Dinaric Western Balkan region, ER 5, Croatia

Vilenica, M., Alegro, A., Koletić, N. \& Mihaljević, Z.: Novi nalaz razmnožavanja vrste Lindenia tetraphylla (Vander Linden, 1825) (Odonata, Gomphidae) na sjeverozapadnoj granici njene rasprostranjenosti. Nat. Croat., Vol. 25, No. 2., 287-294, 2016, Zagreb.

Na akumulaciji Vlačine, smještenoj u dinaridskoj ekoregiji (ER 5, Dinaridski zapadni Balkan) u Hrvatskoj, zabilježeno je ukupno 12 vrsta vretenaca. U radu su prikazani i raspravljeni okolišni uvjeti na istraživanom staništu, prvenstveno struktura vegetacije i fizikalno-kemijski čimbenici vode. Stanišni uvjeti akumulacije bili su pogodni za uspješno završavanje životnog ciklusa mediteranskih vretenaca poput vrsta Lindenia tetraphylla i Selysiothemis nigra. Zabilježeni svlakovi vrste L. tetraphylla predstavljaju novi nalaz razmnožavanja ove vrste na sjeverozapadnoj granici njene rasprostranjenosti.

Ključne riječi: svlakovi, područje razmnožavanja, emergencija, Dinaridska ekoregija, ER 5, Hrvatska

\section{INTRODUCTION}

The Bladetail Lindenia tetraphylla (Vander Linden, 1825) is a large and conspicuous gomphid species distributed from Central Asia and Pakistan to parts of the Arabian Peninsula and the Western Mediterranean Basin (Borisov \& HARITONov, 2008; Boudot, 2014; SChNeIder, 1986, 1988; Schorr et al., 1998; Schröter, 2010a, 2010b; Skvortsov \& Snegovaya, 2014; Stille et al., 2014). In Europe, the species has a disjunct distribution, inhabiting mostly large Mediterranean lakes, with relatively few strong permanent po-

\footnotetext{
* corresponding author: marina.vilenica@gmail.com; marina.vilenica@ufzg.hr
} 
pulations (e.g. Boudot et al., 2009; KALKMAN, 2006). The strongest populations worldwide are found at Lakes Kandahar (Afghanistan) and Doiran (Macedonia/Greece) (observations made by Thomas Schneider). The species is listed in Annexes II and IV of the Habitats Directive, in the European Red List (KaLKman et al., 2010) as vulnerable, in the Croatian Red List (Belančić et al., 2008) as endangered and as a Natura 2000 species (DZZP, 2016).

Larvae predominantly inhabit lakes, but also other stagnant waterbodies and slow flowing rivers with dense and diverse aquatic and riparian vegetation (Boudot, 2014; Schorr et al., 1998; STILle et al., 2014). The adults have high migratory potential and usually travel over long distances from their reproductive site (Boudot et al., 2013). Consequently, the species records often include only adult observations, while evidence of reproduction is more rarely documented (e.g. De Knijf et al., 2013; Kulijer et al., 2013; STILLE et al., 2014).

Although the first studies on the dragonfly fauna of Croatia began in the second half of the $19^{\text {th }}$ century (CARARA, 1846), there is still relatively little published information. Fortunately, our knowledge began to increase during the last quarter of the $20^{\text {th }}$ century (e.g. Bogdanović et al., 2008; Perović \& Perović, 2006; ŠTiн et al., 2011; ŠTiн et al., 2015; Vilenica et al., 2011; VilenicA \& DijKstra, 2014) and the most comprehensive data about the Croatian dragonfly fauna are presented in the Red Book of Dragonflies (BELANčıć et al., 2008). Still, despite the known data, there are still some gaps in our knowledge of Croatian dragonflies, which limits species protection and management of important areas. BELANčić et al. (2008) presented several sites with L. tetraphylla records, five of which were confirmed as reproduction sites. Additionally, there have been several attempts (Franković \& Bogdanović, 2010; Minoković, 2010; Španić et al., 2014) to determine additional suitable sites where the species can complete its life cycle, but without success. Thus, the aims of this paper were to present new data about the distribution and habitat of L. tetraphylla and associated dragonfly species.

\section{METHODS}

\section{Study area}

Vlačine Dam and Reservoir were built in 1969 on Bašćica Stream, located in the Dinaric Western Balkan region in Croatia (Ravni Kotari, SW from the Smilčić village; N 44.15679, E 15.42677; Fig. 1). The average annual rainfall is $929 \mathrm{~mm}$ and the average air temperature $13-14{ }^{\circ} \mathrm{C}$ (PAvlus et al., 2014; Zaninović et al., 2008). Maximal volume of the reservoir is $1130000 \mathrm{~m}^{3}$. The average annual water inflow in the reservoir is $2780000 \mathrm{~m}^{3}$, and during the dry years between 1507000 and $1800000 \mathrm{~m}^{3}$. The main purpose of the dam is to provide a water supply for irrigation of the arable land, but also to collect the excessive water inflow during the autumn and winter. The irrigation is managed in a sustainable way by using rainfall water, which least interferes with subterranean water supply (PAvlus et al., 2014).

\section{Data collection}

Data on the dragonfly fauna of Vlačine Reservoir were collected on July $20^{\text {th }} 2016$, during the period of one hour, until no additional species were found for half an hour. Adult specimens were sampled using an entomological net and the exuviae were collected from the surrounding vegetation and banks by hand. Adult specimens were iden- 


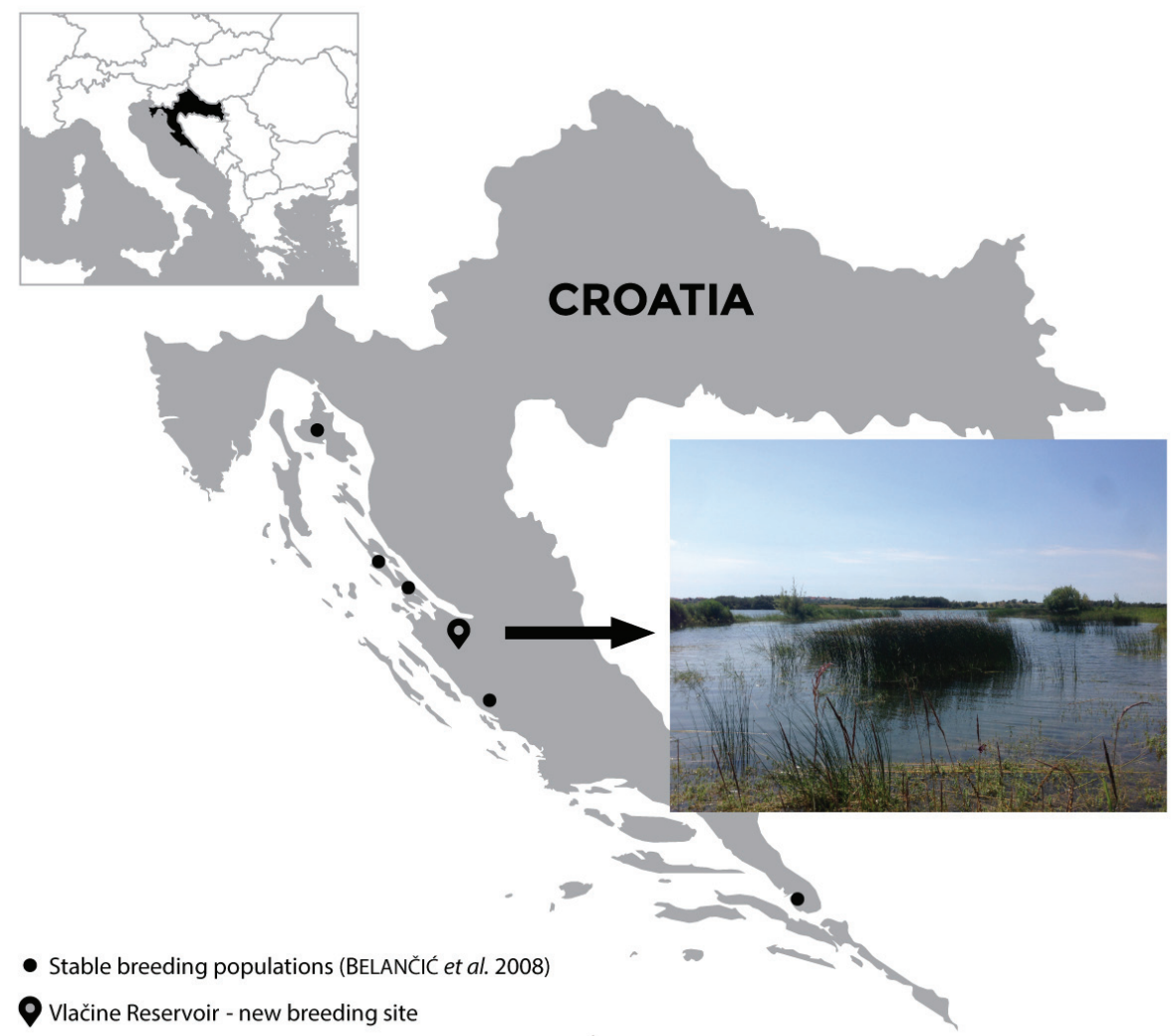

Fig. 1. Lindenia tetraphylla reproduction sites in Croatia, at the north-western border of its distribution, with a photograph of Vlačine Reservoir

tified in the field and released, and exuviae were collected. The adult identification and taxonomy follow Dijkstra \& Lewington (2006). Gerken \& Sternberg (1999) was used for exuviae determination.

Plant nomenclature follows Euro+Med PlantBase (2016).

The physico-chemical water parameters: water temperature, $\mathrm{pH}$, dissolved oxygen concentration, oxygen saturation and conductivity were measured with a multiparameter probe (WTW Multi 3430). Alkalinity (concentration of $\mathrm{CaCO}_{3}(\mathrm{mg} / \mathrm{L})$ ) was measured using Standard Analytical Procedure (APHA).

\section{RESULTS}

A total of 12 dragonfly species were recorded (Tab. 1) in adult stages. Additionally, exuviae of three of the recorded species (L. tetraphylla, Selysiothemis nigra (Vander Linden, 1825), Sympetrum sanguineum (Müller, 1764)) were also documented. Exuviae of L. tetraphylla (Fig. 2) were collected from the fresh and dry vegetation near the reservoir banks, approximately one meter from the water surface. 


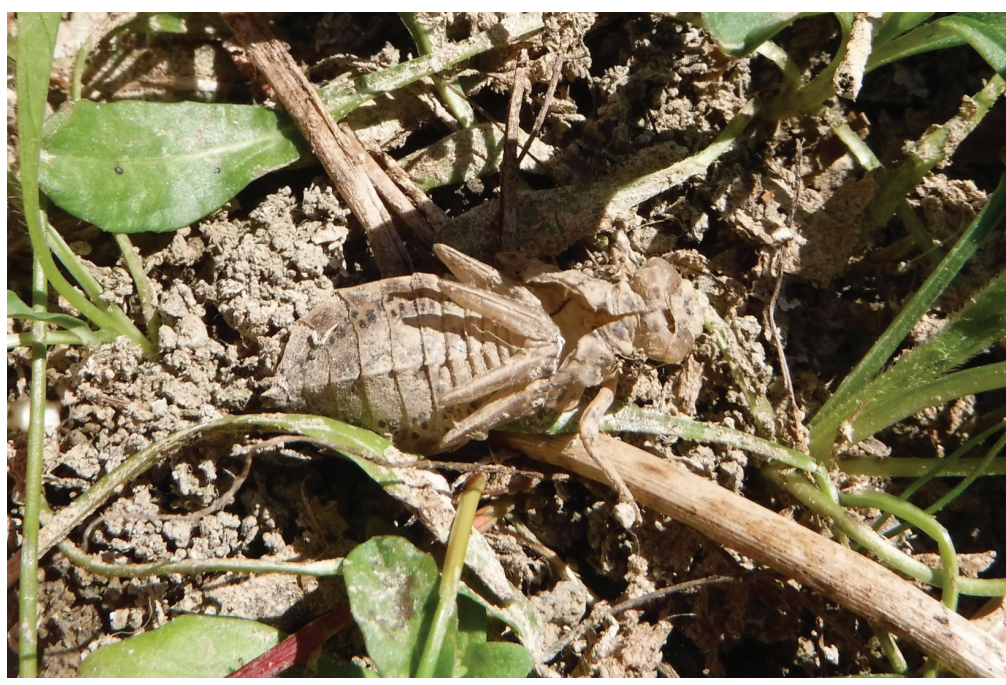

Fig. 2. An exuvia of Lindenia tetraphylla photographed among vegetation on the banks of Vlačine Reservoir (Photo by Dubravka Čerba)

In the reservoir, three main vegetation belts can be recognized: the belt of reeds, a belt of shallow water dominated by helophytes and belt of submerged vegetation. The belt of reeds is dominated by Schoenoplectus lacustris (L.) Palla, which forms an almost continuous ring around the lake. In southern and south-eastern parts of the lake, where banks are less steep and the water shallower, stands of other species occur. The most frequent are Phragmites australis (Cav.) Trin. ex Steud., Arundo donax L. and Typha angu-

Tab. 1. Dragonfly species recorded at Vlačine Reservoir, Croatia. Legend: Relative abundance: 1 - individual record, 3 - several individuals (2-10), 5 - high number of individuals (> 10).

\begin{tabular}{|l|l|l|}
\hline Family & Species & Relative abundance \\
\hline \multirow{4}{*}{ Coenagrionidae } & Coenagrion puella (Linnaeus, 1758) & 5 imagoes \\
\cline { 2 - 3 } & Enallagma cyathigerum (Charpentier, 1840) & 3 imagoes \\
\cline { 2 - 3 } Aeshnidae & Ischnura elegans (Vander Linden, 1820) & 5 imagoes \\
\hline \multirow{3}{*}{ Gomphidae } & Anax imperator Leach, 1815 & 3 imagoes \\
\cline { 2 - 3 } & Anax parthenope (Selys, 1839) & 3 imagoes \\
\hline \multirow{5}{*}{ Libellulidae } & Lindenia tetraphylla (Vander Linden, 1825) & 3 imagoes, 3 exuviae \\
\hline & Crocothemis erythraea (Brullé, 1832) & 3 imagoes \\
\cline { 2 - 3 } & Libellula depressa Linnaeus, 1758 & 3 imagoes \\
\cline { 2 - 3 } & Orthetrum cancellatum (Linnaeus, 1758) & 3 imagoes \\
\cline { 2 - 3 } & Orthetrum coerulescens (Fabricius, 1798) & 5 imagoes \\
\cline { 2 - 3 } & Selysiothemis nigra (Vander Linden, 1825) & 5 imagoes, 3 exuviae \\
\cline { 2 - 3 } & Sympetrum sanguineum (Müller, 1764) & 3 imagoes, 3 exuviae \\
\hline
\end{tabular}


Tab. 2. Physico-chemical water parameters at Vlačine Reservoir, Croatia.

\begin{tabular}{|l|c|}
\hline Physico-chemical parameters & Measured value \\
\hline Air temperature $\left({ }^{\circ} \mathrm{C}\right)$ & 37.50 \\
\hline Air humidity $(\%)$ & 34.00 \\
\hline Water temperature $\left({ }^{\circ} \mathrm{C}\right)$ & 27.20 \\
\hline Dissolved oxygen $(\mathrm{mg} / \mathrm{L})$ & 10.16 \\
\hline Oxygen saturation $(\%)$ & 123.00 \\
\hline Conductivity $(\mu \mathrm{S} / \mathrm{cm})$ & 339.00 \\
\hline pH & 8.15 \\
\hline Alkalinity $\left(\mathrm{CaCO}_{3} \mathrm{mg} / \mathrm{L}\right)$ & 270.00 \\
\hline
\end{tabular}

stifolia L. Like the previous one, the belt of helophytes in shallow water is best developed in the southern and south-eastern parts of the lake. The dominant species here is Gratiola officinalis L., but Mentha aquatica L., Alisma plantago-aquatica L., Baldellia ranunculoides (L.) Parl., Agrostis stolonifera L. and Lythrum salicaria L. also occur with high frequencies, as do two stoneworts, Nitella hyalina (De Candolle) C. Agardh and Chara contraria A. Braun ex Kützing. The most widespread belt is formed of submerged vegetation, and it occupies most of the lake surface except the deepest central parts. The dominant species here, forming dense stands, is Potamogeton lucens L. intermixed with the less abundant P. natans L., P. crispus L., P. perfoliatus L. and Stuckenia pectinata (L.) Börner. Other macrophytes occurring in this belt are Myriophyllum spicatum L., Najas marina L., Veronica anagallis-aquatica L. and Nitellopsis obtusa (N. A. Desvaux) J. Groves, representative of stoneworts.

Physico-chemical water parameters are presented in Tab. 2.

\section{DISCUSSION}

Our observations of Lindenia tetraphylla exuviae represent new evidence of the reproduction of the species at the north-western border of its distribution, which could be important for species and habitat protection and management. According to BeLANčić et al. (2008), the species was recorded as reproducing and forming five stable populations in Croatia: the population in Ponikve and Njivice Lakes on Krk Island, the population in Velo Blato Lake on Pag Island, the population in Vransko Lake near Zadar and the population in the delta of the Neretva River. Even though the species has been studied several times (see in BELANčić et al., 2008), and there have been several relatively recent attempts to detect additional reproduction sites (Мiнокоvić, 2010; Španić et al., 2014), so far none of the studies recorded new sites. Мiнокоvić (2010) and Španić et al. (2014) visited a number of potentially suitable sites that corresponded to habitat descriptions in the literature (DijKSTRA \& LEWINGTON, 2006) or were similar to the species reproductive habitats in Croatia (Belančić et al., 2008). However, some of them were too small in size or did not have the vegetation coverage required by the species. Thus, the species was documented to emerge only at the previously known sites (BELANČić et al., 2008; Мiнокоvić, 2010; Španić et al., 2014). 
BELANČIć et al. (2008) described species habitats in Croatia as predominantly natural Mediterranean lakes, yet a number of studies conducted in southern Europe and the Middle East have reported the species' occurrence in the man-made reservoirs with concrete or stony banks lacking aquatic vegetation (e.g. Kalkman \& VAN Pelt, 2006; Stille et al., 2014; Schneider \& Dumont, 2015; Schneider \& IKemeyer, 2016), which could be a substitute for the former habitats. Still, none of them have reported successful life cycle completion in such habitats. For completing the life cycle at some habitat type, $L$. tetraphylla requires dense riparian vegetation, often with wide stands of Phragmites australis (Cav.) Trin. ex Steud. essential for larval emergence. However, open shore sections without dense vegetation and with sandy substrate have shown to be a very important habitat component of larval ecology (SснолR et al., 1998; Мінокоvić, 2010). Thus, even though it is man-made, Vlačine Reservoir has most of the species' requirements, such as Mediterranean climate, high water temperature, mesotrophic water quality, good oxygen saturation, rich and diverse riparian and aquatic vegetation, shore sections without vegetation and sandy substrate.

Within this study, Selysiothemis nigra, another interesting Mediterranean species was recorded. Lindenia tetraphylla and S. nigra both represent an Iranoeremian faunal element. Consequently, they share similar biogeographical histories, distribution patterns (e.g. LoHMANN, 1981), habitat requirements and can usually be found syntopically (e.g. SchorR et al., 1998; Skvortsov \& Kuvaev, 2010; Uboni et al., 2015). Consequently, during the recent years, both species showed positive population trends in Europe due to the increasing number of suitable man-made habitats (e.g. UtZeri et al., 2006; Boudot, 2014; Stille et al., 2014; UвONi et al., 2015).

The dragonfly species richness recorded at Vlačine Reservoir could be considered relatively high, as some species with disjunct (Mediterranean) (e.g. L. tetraphylla, S. nigra), together with some species with wide European distribution (e.g. C. puella, I. elegans, C. erythraea) were recorded. Since the study was conducted in the midsummer period, the number of species recorded is probably not final. It is expected that more extensive study will record several additional spring species (e.g. Brachytron pratense (Müller, 1764), Pyrrhosoma nymphula (Sulzer, 1776)) and some other species preferring stagnant larger waterbodies with abundant riparian vegetation (e.g. Aeshna mixta Latreille, 1805, Erythromma lindenii (Sélys-Longchamps, 1840)).

Future activities should include detailed monitoring of L. tetraphylla population size at Vlačine Reservoir in order to determine the population's character, i.e. if it is only temporary or long-term, numerous and stable.

\section{Acknowledgements}

The authors would like to thank Vladimir Bartovsky, Dubravka Čerba, Ivana Pozojević and Natalija Vučković for their help during the field investigation and Miran Katar for help with the artwork. The study is a result of a project No. 2016/S 014-0008594 (PL: Zlatko Mihaljević) supported by Hrvatske vode.

Received September 28, 2016

\section{REFERENCES}

Belančić, A., Bogdanović, T., Franković, M., Ljuština, M., Mihoković, N. \& Vitas, B., 2008: Crvena knjiga vretenaca Hrvatske. Ministarstvo kulture, Državni zavod za zaštitu prirode Republike Hrvatske, Zagreb, 132 pp. (In Croatian). 
Bogdanović, T., Merdić, E. \& Mikuska, J., 2008: Data to the dragonfly fauna of the lower Neretva River. Entomologia Croatica 12 (2), 51-65.

Borisov, S.N. \& Haritonov, A.Y., 2008: The dragonflies (Odonata) of Middle Asia. Part 2 (Anisoptera). Euroasian entomological Journal 7, 97-123 (In Russian with English abstract).

Boudot, J.-P., Kalkman, V.J., Azpilicueta Amorín, M., Bogdanović, T., Cordero Rivera, A., Degabriele, G., Dommanget, J.L., Ferreira, S., Garrigós, B., Jović, M., Kotarac, M., Lopau, W., Marinov, M., Minoković, N., Riservato, E., Samraoui, B. \& Schneider, W., 2009: Atlas of the Odonata of the Mediterranean and North Africa. Libellula Supplement 9, 256 pp.

Boudot, J.-P., SchneIder, W. \& SAmraoui, B., 2013: Lindenia tetraphylla. The IUCN Red List of Threatened Species 2013: e. T165460A13372703.http://dx.doi.org/10.2305/IUCN.UK.2013-1. RLTS. T165460A13372703.en. (accessed on 07.08.2016).

Boudot, J.-P., 2014: A brief observation of egg laying in Lindenia tetraphylla (Odonata: Gomphidae) on Kríti (Crete), Greece. Notulae odonatologicae 8 (4), 94-96.

CArrara, F., 1846: La Dalmazia descritta. Fratteli Battala tipografi editori, Zadar.

Dijkstra, K.-D.B. \& Lewington, R., 2006: Field Guide to the Dragonflies of Britain and Europe. British Wildlife Publishing, Gillingham, 320 pp.

De Knijf, G., Vanappelghem, C. \& Demolder, H., 2013: Odonata from Montenegro, with notes on taxonomy, regional diversity and conservation. Odonatologica 42 (1), 1-29.

DZZP, 2016: http://www.dzzp.hr/kategorija/clanak/print.php?id=1242 (accessed on 24.08.2016).

Franković, M. \& Bogdanović, T., 2010: Dragonflies (Insecta: Odonata) of Mljet Island, Croatia and Their Habitats. Proceedings of the Symposium Branimir Gušić Days - Mljet, pp 137-144.

Euro+Med PlantBase, 2016: http://www.emplantbase.org/home.html (accessed on 30.08.2016.).

Gerken, B. \& Sternberg, K., 1999: Die Exuvien europäischer Libellen (Insecta, Odonata). Arnika \& Eisvogel, Höxter, Jena, 354 pp.

Kalkman, V.J., 2006: Key to the dragonflies of Turkey, including species known from Greece, Bulgaria, Lebanon, Syria, the Trans-Caucasus and Iran. Brachytron 10, 3-82.

Kalkman, V.J. \& Van Pelt, G.J., 2006: New records of rare or uncommon dragonflies in Turkey (Odonata). Brachytron 10, 154-162.

Kalkman, V.J., Boudot, J.-P., Bernard, R., Conze, K.-J., de Knijf, G., Dyatlova, E., Ferreira, S., Jović, M., Otт, J., Riservato, E. \& Sahlén, G., 2010: European Red List of Dragonflies. Publications Office of the European Union, Luxembourg.

Kulijer, D., De Knijf, G. \& Franković, M., 2011: Review of the Odonata of Bosnia and Herzegovina. Odonatologica 42 (2), 109-123.

Lohmann, H., 1981: Postglaziale Disjunktionen bei europäischen Libellen. Libellula 1, 2-4.

Мıнокоvić, N., 2010: Monitoring, faunističke i populacijske značajke jezerskog regoča Lindenia tetraphylla (Vander Linden, 1825) u Hrvatskoj. Hrvatsko odonatološko društvo Platycnemis, 32 pp. (In Croatian).

Pavlus, N., Vuković, M., Šegvić, D., Perčić, M., Matošić, B., Petrušić, S., Lukač, G. \& Polić, J., 2014 : Zahtjev za ocjenu o potrebi procjene utjecaja zahvata na okoliš „Rekonstrukcija sustava navodnjavanja Bašćica - II. faza, podsustav Smilčić, CS Kašić sa dovodnim i tlačnim cjevovodom“. Zeleni servis d.o.o., Split, 104 pp. (In Croatian).

Perović, G. \& Perović, F., 2006: Preliminami rezultati istraživanja vretenaca (Odonata) na području Međimurja, Hrvatska. Entomologia Croatica 10 (1-2), 87-103.

Schorr, M., Schneider, W. \& Dumont, H.J., 1998: Ecology and distribution of Lindenia tetraphylla (Insecta, Odonata, Gomphidae): a review. - International Journal of Odonatology 1, 65-88.

SchneIDER, W., 1986: Systematik und Zoogeographie der Odonata der Levante unter besonderer Berücksichtigung der Zygoptera. Dissertation, Universität Mainz, 202 pp.

Schneider, W., 1988: Dragonflies (Odonata) of the Wahiba Sands and adjacent Areas, Eastern Oman. Journal of Oman Studies, Special Report 3, 377-388.

Schneider, T. \& Dumont, H. J., 2015: Odonata records from southern Iran. Notulae odonatologicae 8(5), 117-155.

Schneider, T. \& Ikemeyer, D., 2016: Notes on Odonata species in South-West Iran including Platycnemis kervillei (Martin, 1909) as a new species for Iran. Entomologische Zeitschrift 126 (1), 3-8.

Schröter, A., 2010a: On a collection of dragonflies from eastern Georgia, with the first record of Sympetrum arenicolor (Odonata: Libellulidae). Libellula 29, 209-222.

Schröter, A., 2010b: The Odonata of Kyrgyzstan, part I - Critical national checklist, annotated list of records and collected data of the summer half-years 2008 and 2009. International Dragonfly FundReport 28, 1-72. 
Skvortsov, V. \& Kuvaev, A., 2010: Ischnura fountaineae Morton, Lindenia tetraphylla (Vander Linden) and Selysiothemis nigra (Vander Linden) new for European Russia (Zygoptera: Coenagrionidae; Anisoptera: Gomphidae, Libellulidae). Notulae Odonatologicae 7 (5), 49-51.

Skvortsov, V.E. \& SNEgovaya, N.Yu., 2014: Additions to the knowledge of the Odonata fauna of Azerbaijan, with six new records. Notulae odonatologicae 8 (3), 67-76.

Stille, M., Stille, B. \& Schröter, A., 2014: Lindenia tetraphylla - new for the island of Kérkira (Corfu), Greece (Odonata: Gomphidae). Notulae odonatologicae 8 (4), 86-90.

Španić, R., Vilenica, M. \& ŠEgota, V., 2014: Program za praćenje stanja jezerskog regoča (Lindenia tetraphylla) u Hrvatskoj. IRES - Institut za istraživanje i razvoj održivih ekosustava, 18 pp. (In Croatian).

Štih, A., Zadravec, M., Hlavati, D. \& Koren, T., 2011: First data on dragonfly (Insecta, Odonata) fauna in the Vugrovec area, Zagreb and the first checklist of the dragonflies of Zagreb. Entomologia Croatica 15 (1-4), 223-235.

Štih, A., Koren, T., Bobinec, A., Matejčić, M. \& Franković, M., 2015: The River Zrmanja - Another Hotspot of Dragonfly Diversity in the Dinaric Karst, Croatia. Entomologia Croatica 19 (1-2), 43-57.

Uboni, C., NAdAlon, G., Schröter, A., 2015: Evidence of breeding of Selysiothemis nigra in the regions of Friuli Venezia Giulia and Veneto, northeastern Italy (Odonata: Libellulidae). Notulae odonatologicae 8 (5), 117-155.

Utzeri, C., Belfiore, C. \& Peels, F., 2006: Some new records of Lindenia tetraphylla (Vander Linden) in Italy (Anisoptera Gomphidae). Notulae odonatologicae, 6 (8): 90-92.

Vilenica, M., Mičetić Stanković, V. \& Franković, M., 2011: Dragonfly fauna (Insecta, Odonata) in the Turopolje region (Croatia). Natura Croatica 20 (1), 141-15.

VilenicA, M. \& Dijkstra, K.-D. B., 2014: The dragonfly (Insecta, Odonata) fauna of the Banovina region, Croatia. Natura Croatica 23 (1), 45-66.

Zaninović, K., Gajić-Čapka, M., Perčec Tadić, M., Vučetić, M., Milković, J., Bajić, A., Cindrić, K., Cvitan, L., Katušin, Z., Kaučić, D., Likso, T., Lončar, E., Lončar, Ž., Mihajlović, D., Pandžić, K., Patarčić, M., SRnec, L., VučEtić, V., 2008: Klimatski atlas Hrvatske / Climate atlas of Croatia 19611990., 1971-2000. Državni hidrometeorološki zavod, Zagreb, 200 pp. (In Croatian).

\title{
SUMMARY
}

\section{New evidence of Lindenia tetraphylla (Vander Linden, 1825) (Odonata, Gomphidae) reproduction at the north-western border of its distribution}

\author{
M. Vilenica, A. Alegro, N. Koletić \& Z. Mihaljević
}

Lindenia tetraphylla is a large, highly migratory dragonfly species representing an Iranoeremian faunal element. In Europe, the species has a disjunct distribution, mainly inhabiting large Mediterranean lakes, with relatively few strong permanent populations. In Croatia, the species was previously recorded as reproducing and forming five stable populations, mainly at large Mediterranean lakes. Additional reproducing sites have not previously been documented. Even though it is man-made, Vlačine Reservoir has suitable habitat conditions for species' life cycle completion, i.e., a Mediterranean climate, high water temperature, mesotrophic water quality, good oxygen saturation, rich and diverse riparian and aquatic vegetation, shore sections without vegetation and a sandy substrate. Within this study, life cycle completion was recorded for another interesting Mediterranean species, Selysiothemis nigra. 